\title{
Aviation radiative forcing in 2000: An update on IPCC (1999)
}

\author{
Robert SAusen ${ }^{* 1}$, IVAr ISAKSen ${ }^{2}$, Volker Grewe ${ }^{1}$, Didier Hauglustaine ${ }^{3}$, DaVid S. LeE ${ }^{4}$, \\ Gunnar Myhre ${ }^{2}$, Marcus O. Köhler ${ }^{5}$, Giovanni Pitari ${ }^{6}$, Ulrich Schumann ${ }^{1}$, Frode \\ STORDAL $^{2}$ and CHRISTOS ZEREFOS ${ }^{7}$
}

\author{
${ }^{1}$ DLR, Institut für Physik der Atmosphäre, Oberpfaffenhofen, Germany \\ ${ }^{2}$ Department of Geosciences, University of Oslo, Norway \\ ${ }^{3}$ Laboratoire des Sciences du Climat et de l'Environnement, Unité Mixte de Recherche CEA-CNRS, Gif-sur- \\ Yvette, France \\ ${ }^{4}$ Dalton Research Institute, Manchester, Manchester Metropolitan University, Manchester, United Kingdom \\ ${ }^{5}$ Centre for Atmospheric Science, Department of Chemistry, University of Cambridge, Cambridge, United \\ Kingdom \\ ${ }^{6}$ Dipartimento di Fisica, Universita' L'Aquila, Italy \\ ${ }^{7}$ Laboratory of Climatology and Atmospheric Environment, University of Athens and FBR, Academy of Athens, \\ Greece
}

(Manuscript received September 14, 2004; in revised form May 24, 2005; accepted June 1, 2005)

\begin{abstract}
New estimates of the various contributions to the radiative forcing (RF) from aviation are presented, mainly based on results from the TRADEOFF project that update those of the Intergovernmental Panel on Climate Change (IPCC, 1999). The new estimate of the total RF from aviation for 2000 is approximately the same as that of the IPCC's estimate for 1992. This is mainly a consequence of the strongly reduced RF from contrails, which compensates the increase due to increased traffic from 1992 to 2000 . The RF from other aviationinduced cirrus clouds might be as large as the present estimate of the total RF (without cirrus). However, our present knowledge on these aircraft-induced cirrus clouds is too poor to provide a reliable estimate of the associated RF.

\section{Zusammenfassung}

Neue Abschätzungen der einzelnen Beiträge zum Strahlungsantrieb des Luftverkehrs werden vorgestellt, die im Wesentlichen auf Ergebnissen des TRADEOFF-Projektes beruhen und die die IPCC-Abschätzungen (1999) aktualisieren. Der neue Wert für den gesamten Strahlungsantrieb des Luftverkehrs im Jahr 2000 ist in etwa gleich groß wie die IPCC-Abschätzung für das Jahr 1992. Das ist im Wesentlichen eine Folge des stark reduzierten Strahlungsantriebes durch Kondensstreifen, wodurch der Anstieg aufgrund der Zunahme des Verkehrs von 1992 bis 2000 kompensiert wird. Der Antrieb durch andere luftverkehrsinduzierte Wolken könnte ebenso groß sein wie die neue Abschätzung für den gesamten Strahlungsantrieb (ohne Zirren). Jedoch ist unser heutiges Wissen über diese luftverkehrsinduzierten Wolken nicht gut genug, um belastbare Aussagen über den damit verbundenen Strahlungsantrieb zu machen.
\end{abstract}

\section{Introduction}

More than 5 years have passed since the publication of the 1999 IPCC Special Report "Aviation and the Global Atmosphere" (PENNER et al., 1999). In 2003, the European Conference on Aviation, Atmosphere and Climate (AAC) in Friedrichshafen, Germany (SAUSEN et al., 2004) provided an update to our knowledge on this topic. A central outcome of the 1999 IPCC report was an estimate of the radiative forcing (RF) arising from the different aviation-induced perturbations to the atmosphere, e.g., their Figure 6-14. Here we present an up-

\footnotetext{
*Corresponding author: Robert Sausen, Institut für Physik der Atmosphäre, DLR Oberpfaffenhofen, 82234 Wessling, Germany, e-mail: robert.sausen@dlr.de
}

date of this figure, which accounts for advances in science.

Note that RF (e.g., SHINE et al., 1990) is considered as a metric of climate change (FUGLESTVEDT et al., 2003): for many perturbations of species radiatively active in the atmosphere, in particular for well-mixed greenhouse gases, the radiative forcing RF is proportional to the expected equilibrium climate change in terms of global mean surface temperature change $\Delta T_{s}$,

$$
\Delta T_{s}=\lambda R F,
$$

where $\lambda$ is the climate sensitivity parameter (unit $\left.\mathrm{K} /\left(\mathrm{Wm}^{-2}\right)\right)$. The use of equation (1.1) implicitly assumes that $\lambda$ is independent of the forcing mechanism. 


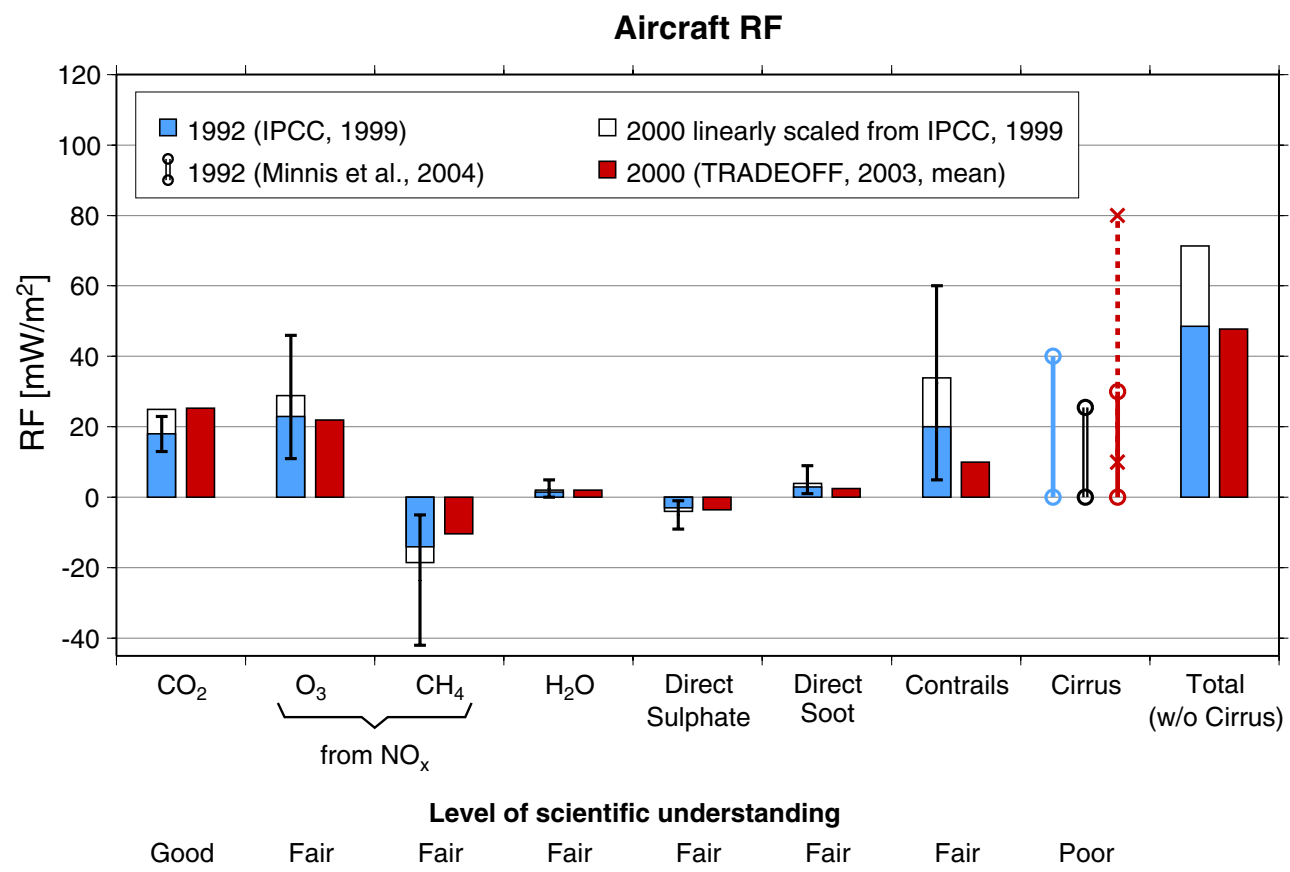

Figure 1: RF $\left[\mathrm{mW} / \mathrm{m}^{2}\right.$ ] from aviation for 1992 and 2000, based on IPCC (1999) and TRADEOFF results. The whiskers denote the 2/3 confidence intervals of the IPCC (1999) value (see main text for further details). The lines with the circles at the end display different estimates for the possible range of RF from aviation induced cirrus clouds. In addition the dashed line with the crosses at the end denote an estimate of the range for RF from aviation induced cirrus. The total does not include the contribution from cirrus clouds.

However, it is well documented that $\lambda$ varies by more than a factor of two among models, reflecting, e.g., different parameterisations implemented (e.g., CESs et al., 1990; Prather et al., 1999). The proportionality in equation (1.1) forms one of the bases for the Kyoto Protocol and for emissions trading of the gases in the Kyoto "basket", as RF is one of the terms entering the Global Warming Potential (GWP).

Recent studies (e.g., STUBER et. al., 2001; JoshI et al., 2003; CoOK and Highwood, 2003) have shown that $\lambda$ is not constant for a range of perturbations to radiatively active species, in particular if the additional radiatively active species are inhomogeneously distributed, as is the case for aviation-induced ozone changes. Already PrATHER et al. (1999) pointed out this problem, and this also has implications for including aviation in emissions trading (LEE and SAUSEN, 2000). Despite these caveats we assume that equation (1.1) is approximately valid, and that therefore, calculating aviation RF allows a comparison of aviation-induced climate change with other anthropogenic impacts.

\section{IPCC results for 1992}

The blue bars in Figure 1 (see also Table 1) display the IPCC aviation RFs for the year 1992 from PRATHER et al. (1999). The most prominent positive contributions (warming) are from $\mathrm{CO}_{2}, \mathrm{O}_{3}$ and (linear) contrails, which are of approximately the same magni- tude $\left(\sim 20 \mathrm{~mW} / \mathrm{m}^{2}\right)$. A negative contribution (cooling) of similar magnitude results from $\mathrm{CH}_{4}$ changes $\left(-14 \mathrm{~mW} / \mathrm{m}^{2}\right)$. Smaller contributions arise from water vapour and the direct (radiative) effects of sulphate and soot aerosols. All these values are "best estimates" that sum up to a total of $48.5 \mathrm{~mW} / \mathrm{m}^{2}$.

PRATHER et al. (1999) did not provide a best estimate for the aircraft effect on cirrus clouds (beyond linear contrails) due to the very poor knowledge available. But rather a range for the potential best estimates was given (Table 2), i.e., the top of the blue line with the circle at the ends (Figure 1) gives an estimate of the upper limit for the contribution of aviation-induced cirrus changes $\left(40 \mathrm{~mW} / \mathrm{m}^{2}\right)$. Since a best estimate could not be provided, the total aviation RF did not include the cirrus effect.

Recently, MinNis et al. (2004) provided another upper estimate (double black lines with circles at the ends in Figure 1) for the aviation-induced cirrus changes $\left(25.5 \mathrm{~mW} / \mathrm{m}^{2}\right)$. Their estimate is based on additional information that was not available to PRATHER et al. (1999). Note that the MinNis et al. (2004) estimate includes the contribution from linear contrails, i.e., the MinNIS et al. value is considered an upper estimate of the total aviation induced cloud effects (contrails plus other cirrus clouds).

Except for the total, the whiskers in Figure 1 display the $2 / 3$ confidence intervals of PRATHER et al. (1999), i.e., they provide $2 / 3$ or $67 \%$ probability ranges that are 
Table 1: Radiative forcings (RFs) from aviation $\left[\mathrm{mW} / \mathrm{m}^{2}\right]$. The best estimates for 1992 by IPCC (1999) and two estimates for 2000 are given: one is derived from IPCC (1999) by linear interpolation, the second is based on the mean values resulting from the TRADEOFF project. As in IPCC (1999), the TRADEOFF RFs for $\mathrm{CO}_{2}, \mathrm{O}_{3}$ and $\mathrm{CH}_{4}$ were scaled by a factor of 1.15 . The $\mathrm{RFs}$ from $\mathrm{O}_{3}$ and $\mathrm{CH}_{4}$ are both a result of aircraft $\mathrm{NO}_{x}$ emissions.

\begin{tabular}{|ll|r|r|r|r|r|r|r|r|}
\hline & \multicolumn{9}{|c|}{ RF [mW/m $\left.{ }^{2}\right]$} \\
\hline Year & Study & $\mathbf{C O}_{2}$ & $\mathbf{O}_{3}$ & $\mathbf{C H}_{4}$ & $\mathbf{H}_{2} \mathbf{O}$ & $\begin{array}{r}\text { Direct } \\
\text { Sulphate }\end{array}$ & $\begin{array}{r}\text { Direct } \\
\text { Soot }\end{array}$ & Contrails & $\begin{array}{r}\text { Total } \\
\text { (w/o) Cirrus }\end{array}$ \\
\hline 1992 & IPCC (1999) & 18.0 & 23.0 & -14.0 & 1.5 & -3.0 & 3.0 & 20.0 & 48.5 \\
2000 & IPCC (1999) scaled to 2000 & 25.0 & 28.9 & -18.5 & 2.0 & -4.0 & 4.0 & 33.9 & 71.3 \\
2000 & TRADEOFF & 25.3 & 21.9 & -10.4 & 2.0 & -3.5 & 2.5 & 10.0 & 47.8 \\
\hline
\end{tabular}

Table 2: Different estimates of the upper bound of the potential range for the radiative forcings (RFs) from aviation-induced cirrus clouds $\left[\mathrm{mW} / \mathrm{m}^{2}\right]$ and a new "mean" estimate. Note that the MinNIS et al. (2004) value includes linear contrails.

\begin{tabular}{|l|l|c|c|}
\hline Year & Study & $\begin{array}{c}\text { Estimated “mean" } \\
\text { for aviation-induced } \\
\left.\text { cirrus RF [mW/m }{ }^{2}\right]\end{array}$ & $\begin{array}{c}\text { Upper bound for } \\
\text { aviation-induced } \\
\left.\text { cirrus RF [mW/m }{ }^{2}\right]\end{array}$ \\
\hline 1992 & IPCC (1999) & & 40 \\
\hline 1992 & MINNIS et al. (2004) & & 26 \\
\hline 2000 & TRADEOFF & 30 & 80 \\
\hline
\end{tabular}

meant to be symmetrical about the best estimate. The best estimate is not always the mean of the upper and lower values. The probability that the true value is less than the lower value is $16 \%$, and the probability that it is less than the upper value is $84 \%$. The range between the low and high values is equivalent to the " 1 -sigma" range of a normal (i.e., Gaussian) probability distribution. The derivation of these confidence intervals lay with the expert judgement of the scientists contributing to IPCC (1999) and included a combination of objective statistical models with subjective expertise. Thus, the $67 \%$ confidence intervals do not imply a specific statistical model.

\section{An IPCC-based estimate for 2000}

PrATHER et al. (1999) also provided estimates of the aviation RF for the year 2015. By linear interpolation of the RF for 1992 and 2015, we calculated the RF for the year 2000 (Table 1). The results are displayed by open bars behind the blue bars in Figure 1. These are the results that PRATHER et al. (1999) would have shown if they had provided numbers for 2000 and are the results that we will compare our new estimates for 2000 with.

\section{The TRADEOFF estimate}

In TRADEOFF, an EU FP5 research project (20002003), several groups worked on new estimates of the radiative forcings from aviation. The red bars in Figure 1 represent the TRADEOFF mean values for the year 2000 (see also Table 1).

Since a detailed emissions inventory was not available for the year 2000, a 1991/92 movements base year was projected, corrected by ICAO statistics through to 2000 and converted into emissions, fuel burn and distance travelled. The total fuel burn (civil and military) was $169 \mathrm{Tg}$ per year and the $\mathrm{NO}_{x}$ emissions $2.16 \mathrm{Tg}$ $\mathrm{NO}_{x}\left(\right.$ as $\left.\mathrm{NO}_{2}\right)$ per year. These calculations are in good agreement with the estimate for 2000 used in the Third IPCC Assessment Report (IPCC, 2001). A more detailed inventory has recently become available from the EU FP5 project AERO2K. As in PRATHER et al. (1999), the RFs from $\mathrm{CO}_{2}, \mathrm{O}_{3}$ and $\mathrm{CH}_{4}$ were scaled by a factor of 1.15 in order to account for extra fuel burn, which results from imperfect routing, sub-optimal cruise altitude, holdings, etc.

The RF from aviation $\mathrm{CO}_{2}\left(22 \mathrm{~mW} / \mathrm{m}^{2}\right.$, scaled to $25 \mathrm{~mW} / \mathrm{m}^{2}$ ) does not differ from the IPCC-based estimate for 2000. The fuel burn grew somewhat faster than estimated by IPCC (1999). However, this is compensated by a slightly smaller RF per unit $\mathrm{CO}_{2}$ increase (IPCC, 2001).

In order to determine the RF from aircraft-induced $\mathrm{O}_{3}$ increase and $\mathrm{CH}_{4}$ loss, the perturbations to the abundance of these species resulting from aviation $\mathrm{NO}_{x}$ emissions were calculated with five new-generation Chemical Transport Models (CTMs) and Climate-Chemistry Models (CCMs): TOMCAT (University of Cambridge: LAW et al., 2000; KÖHLER, 2003), CTM-2 (University of Oslo: KRAABøL et al., 2002; GAUSS et al., 2003a, 2003b), ECHAM4.L39(DLR)/CHEM (DLR: HEIN et al., 2001; GREWE et al., 2002), LMDz-INCA (LSCE: HAUGLUSTAINE et al., 2004) and ULAQ (University of L'Aquila: PITARI et al., 2002). The models listed above have been evaluated by BRUNNER et al. (2003, 2005). While the aircraft-induced $\mathrm{O}_{3}$ perturbation was directly simulated, the $\mathrm{CH}_{4}$ change was estimated from a change 
in $\mathrm{CH}_{4}$ lifetime (BERNTSEN et al., 2004) resulting from an $\mathrm{OH}$ change in analogy to the method applied by e.g., DERWENT et al. (1999) or ISAKSEN et al. (1999). Finally, the radiative forcings from these perturbations were calculated using off-line radiative transfer codes, yielding forcings in the range $12-28 \mathrm{~mW} / \mathrm{m}^{2}$. (The range results mainly from different ozone perturbations.) The average value is $19 \mathrm{~mW} / \mathrm{m}^{2}$ (scaled to $22 \mathrm{~mW} / \mathrm{m}^{2}$ ), which we take as our best estimate. This is somewhat smaller than the IPCC-based estimate for 2000; however, in the light of the large $2 / 3$ confidence interval this difference is not significant. The corresponding $\mathrm{RF}$ from aircraft-induced $\mathrm{CH}_{4}$ loss (mean: $-9 \mathrm{~mW} / \mathrm{m}^{2}$, scaled to $-10 \mathrm{~mW} / \mathrm{m}^{2}$ ) is only about half the IPCC-based estimate. The new value still is within the $2 / 3$ confidence interval of PRATHER et al. (1999). Current estimates of $\mathrm{O}_{3}$ and $\mathrm{CH}_{4}$ lifetime perturbations from aircraft emissions give somewhat smaller values than those reported in the IPCC (1999) study. Furthermore, the number of models participating in TRADEOFF was smaller than the number of models contributing to PRATHER et al. (1999). This may explain some of the discrepancy between the IPCC (PRATHER et al., 1999) and the TRADEOFF results.

The changes to the RFs from water vapour, direct sulphate and direct soot are minor and will therefore not be discussed further.

The biggest change from the IPCC results (see also MINNIS et al., 1999) is the RF from (linear) contrails, which has been calculated to be about $10 \mathrm{~mW} / \mathrm{m}^{2}$ $\left(6 \mathrm{~mW} / \mathrm{m}^{2}\right.$ scaled from MARQUART et al. (2003), who calculated 3.5 and $9.8 \mathrm{~mW} / \mathrm{m}^{2}$ for the years 1992 and 2015, resp.; $15 \mathrm{~mW} / \mathrm{m}^{2}$ scaled from MYHRE and STORDAL (2001), who calculated $9 \mathrm{~mW} / \mathrm{m}^{2}$ for the year 1992). It is approximately a factor of three to four smaller than the IPCC-based estimate (Table 1). The new estimate of MARQUART et al. (2003) is based on more observations of contrails (e.g., MEYER et al., 2002), refined parameterisations of contrail coverage and contrail microphysical properties (e.g., PONATER et al., 2002; MARQUART and MAYER, 2002), and takes the temporal and spatial variation of the background atmosphere into account. The estimate of MYHRE and STORDAL (2001) would be somewhat lower than the estimated $15 \mathrm{~mW} / \mathrm{m}^{2}$ if lower contrail cover and optical depth were included, but is still likely to be larger than the estimate of MARQUART et al. (2003). The new best estimate is just at the lower edge of the IPCC $2 / 3$ confidence interval of PRATHER et al. (1999), which was estimated for the year 1992. Note that the MARQUART et al. (2003) estimate for $1992\left(3.5 \mathrm{~mW} / \mathrm{m}^{2}\right)$ is outside the IPCC confidence interval.

Due to the strong decrease in the estimate for the TRADEOFF contrail RF, the new total $\left(48 \mathrm{~mW} / \mathrm{m}^{2}\right)$ is smaller than the IPCC-based estimate for 2000 and marginally smaller than the IPCC value for 1992 $\left(48.5 \mathrm{~mW} / \mathrm{m}^{2}\right)$. As in PRATHER et al. (1999), the total does not include the contribution from aircraft induced cirrus changes beyond linear contrails. We did not provide confidence intervals for TRADEOFF mean values of RFs, because we consider that the number of independent estimates for the individual contributions is too small to provide reliable confidence intervals.

At the bottom of Figure 1 the current level of scientific understanding is indicated, with the grades "good", "fair" and "poor". This is a measure independent of the magnitude of the $2 / 3$ confidence intervals. Actually, the level of scientific understanding can be "good" while at the same time the $2 / 3$ confidence interval is large, due to high internal variability of the process considered. The grades are, as was with IPCC (1999), based on subjective expert judgement. But contrary to IPCC (1999) we use fewer grades, only 3, as these grades are a quite crude judgement and, therefore, any finer categories would introduce more subjectivity.

\section{Cirrus clouds}

Apart from triggering linear contrails, aviation has the potential to change cirrus clouds in the following ways:

(1) Contrails do not always evaporate after some minutes. If the background atmosphere is sufficiently supersaturated with respect to the ice phase, they can grow to larger cirrus clouds, called contrail cirrus, which cannot be distinguished from natural cirrus clouds if their history is unknown. The formation of such contrail cirrus has been observed (SCHUMANN and WENDLING, 1990; Minnis et al., 1998). MANNSTEIN and SCHUMANN (2005) estimated that the cover by contrail cirrus in central Europe is approximately 10 times larger than the cover by linear contrails.

(2) Aircraft directly emit particles (e.g., soot) and also precursors of volatile particles (e.g., sulphur oxides). These aerosols are eventually transformed into cloud condensation nuclei, which may trigger the formation of cirrus clouds much later than the original emission, if the background atmosphere has changed to a state allowing cloud formation (supersaturation). An observational proof of this effect is still lacking although theory allows this process. An indication of such an effect might be extracted from STRÖM and OHLSON (1998).

(3) Aircraft-induced aerosols can additionally modify the micro-physical properties of cirrus clouds, change cloud particle sizes and forms, and the number of cloud particles (KRISTENSSON et al., 2000; KÄRCHER and LOHMANN, 2003). The result of such modification may include a change in the precipitation rate, in cloud lifetime and in cloud radiative properties. A quantification of this effect is still the subject of research. 
In TRADEOFF, two independent studies have been made of trends in cirrus cloudiness, both seeking to extract the trend due to air traffic (ZEREFOs et al., 2003 and STORDAL et al., 2005). The two studies were based on cloud data from ISCCP (International Satellite Cloud Climatology Project) but used different statistical approaches. STORDAL et al. (2005) calculated trends in cirrus cloud cover based on 16 years of cloud data. They correlated the trends spatially with aircraft density data to determine the changes in cirrus cloud cover due to aviation. In their study, the main emphasis was on the area covered by the METEOSAT satellite to avoid spurious trends in the ISCCP data resulting from changing satellite positions. In Europe, which is within the METEOSAT region, their analysis resulted in a trend of about 1 to $2 \%$ per decade due to aircraft. This finding is very similar to the one derived for Europe by ZEREFOS et al. (2003), who, after removing the influences of natural phenomena (such as ENSO, QBO, NAO and tropopause variability), found an increase in cirrus cover in high air traffic areas over Europe of $+1.3 \%$ per decade, contrasting with a decrease of $-0.2 \%$ per decade in adjacent low air traffic areas. Similar positive trends in cirrus were found in other regions with high aircraft density.

STORDAL et al. (2005) extrapolated their result in time to cover a longer period of aircraft operations and the global scale, assuming the radiative efficiency of cirrus to equal that of contrails. This yielded a "mean" RF of $30 \mathrm{mWm}^{-2}$, associated with a large uncertainty range of 10 to $80 \mathrm{mWm}^{-2}$. (This range includes estimated uncertainties in the spatial correlation between trends in observed cirrus cover and aviation as well as uncertainties in the radiative impact per unit cloud cover.)

Both the studies of ZEREFOS et al. (2003) and STORDAL et al. (2005) are based primarily on correlation analyses. Such studies can provide statistical evidence of an association between aviation and observed changes in cloudiness, but do not prove causality. Coincidentally, the heaviest air traffic is found in regions where the subtropical and the subpolar jets are often found, i.e., the cloudiness in these regions is potentially sensitive to decadal natural climate variability and to anthropogenic climate change (from greenhouse gases). Therefore, we have reservations in considering the RF above as a best estimate; it rather is at least an order of magnitude estimate of the RF from aircraft-induced cirrus changes.

The new "mean" estimate (STORDAL et al., 2005) is about $25 \%$ smaller than the IPCC upper limit given by FAHEY et al. (1999), while the new "upper bound" is about $90 \%$ higher than the IPCC upper limit and about three times as high as the upper value given by MINNIS et al. (2004), see also Table 2. Note that both IPCC (1999) and MinNis et al. (2004) refer to 1992, whereas the new value is for 2000, which has increased traffic over 1992.

Furthermore, good reasoning exists that RF for aviation-induced cirrus changes is positive: optically thin cirrus clouds are known to warm climate on average (HARTMANN et al., 1992), although occasionally (and regionally) RF from aviation-induced cirrus can be negative (e.g., MEERKÖTTER et al., 1999; MYHRE and STORDAL, 2001; MEYER et al., 2002; MANNSTEIN and SCHUMANN, 2005). The assumption that the radiative efficiency of cirrus equals that of contrails is highly uncertain. Nevertheless, we expect from the current knowledge that the best estimate of aviation-induced cirrus $\mathrm{RF}$ is somewhere between zero and an estimated upper bound. Due to this lack of knowledge it is not yet possible to add the RF for aviation-induced cirrus changes to the total aviation RF. Evidently, if the actual value was close to the "mean" value of STORDAL et al. (2005), the total RF would increase substantially, and consequently aviation's share to the total anthropogenic RF.

\section{Conclusion}

The TRADEOFF project has provided an update to the aviation-induced radiative forcings (RFs). The most prominent change is that RF from (linear) contrails has been strongly reduced, by a factor of approximately three to four. The RFs from $\mathrm{CO}_{2}, \mathrm{O}_{3}$, and $\mathrm{CH}_{4}$ are smaller than expected from increase in air traffic. Because of the reduced estimate of the RF from contrails, the new total for $2000\left(48 \mathrm{~mW} / \mathrm{m}^{2}\right)$ is about the same as the total provided by PRATHER et al. (1999) for the year 1992.

As in the IPCC report (PRATHER et al., 1999) the new TRADEOFF estimate does not include the contribution from aviation induced cirrus clouds. It is possible that the total aviation RF could be twice as large as the total RF given here. Potentially, the range for an estimate of RF from aviation induced cirrus clouds is much larger than the IPCC estimate. Therefore, more research is needed to reliably quantify the RF from aviationinduced changes of cirrus clouds ${ }^{1}$.

It should be noted that the formation of contrails, and hence also the formation of contrail cirrus, depends on future background climate through changes in water vapour and chemical composition in a warmer atmosphere. Furthermore, the formation of contrails and the associated RF depend on cruise altitude (FICHTER et al., 2005). If this contribution of contrail cirrus to the total aviation RF is really as large as the upper estimate given in this paper, it therefore is worthwhile to investigate methods to reduce the effect by different procedures

\footnotetext{
${ }^{1}$ Such research will be undertaken in, e.g., the EU FP6 Integrated Project QUANTIFY and the HGF project PAZI-2.
} 
for selecting flight routes and altitudes, e.g., by searching routes and altitudes that minimise the formation of aircraft induced clouds (cf. SAUSEN et al., 1996).

\section{Acknowledgements}

The research on which this article is based was funded by the Commission of the European Union (TRADEOFF project). We thank Dr. Georgios AMANATIDIS for encouraging us to write this paper and Axel LAUER for preparing the figure. We also would like to thank the anonymous reviewers for their helpful comments.

\section{References}

BerntSEn, T.K., M. GAuss, I.S.A. ISAKSEN, V. GRewe, R. Sausen, G. Pitari, E. Mancini, E. MeiJer, D. Hauglustaine, 2004: Sources of $\mathrm{NO}_{x}$ at cruise altitudes: Implications for predictions of ozone and methane perturbations due to $\mathrm{NO}_{x}$ from aircraft. - In R. SAUSEN, C. Fichter, G. AmANATIDIS (Eds): European Conference on Aviation, Atmosphere and Climate (AAC). Proceedings of an International Conference Friedrichshafen, Germany, 30 June to 3 July 2003, EUR 21051, 190-196.

BrunNer, D., J. Staehelin, H.L. Rogers, M.O. KÖHLer, J.A. Pyle, D. Hauglustaine, L. Jourdain, T.K. Berntsen, M. Gauss, I.S.A. Isaksen, E. MeIJer, P. VAN Velthoven, G. Pitari, E. MANCini, V. GREWE, R. SAUSEN, 2003: An evaluation of the performance of chemistry transport models by comparison with research aircraft observations. Part 1: Concepts and overall model performance. - Atmos. Chem. Phys. 3, 1609-1631.

Brunner, D., J. Stae HELIN, H.L. ROGERS, M.O. KÖHLer, J.A. Pyle, D.A. Hauglustaine, L. Jourdain, T.K. Berntsen, M. Gauss, I.S.A. Isaksen, E. MeIJer, P. VAN Velthoven, G. Pitari, E. MANCini, V. GRewe, R. SAuSen, 2005: An evaluation of the performance of chemistry transport models - Part 2: Detailed comparison with two selected campaigns. - Atmos. Chem. Phys. 5, 107-129.

CESS, R.D., G.L. PotTer, J.P. Blanchet, G.J. Boer, G.-A.D. Del, M. Deque, V. Dymnikov, V. Galin, W.L. Gates, S.J. Ghan, J.T. Kiehl, A.A. Lacis, T.H. LE, Z.X. Li, X.Z. LiAnG, B.J. MCAVANEY, V.P. Meleshio, J.F.B. Mitchell, J.J. Morcrette, D.A. RANDALL, L. RIKUS, E. ROECKNER, J.-F. ROYER, U. Schlese, D.A. Sheinin, A. Slingo, A.P. Sokolov, K.E. TAYLOR, W.M. WASHINGTON, R.T. WETHERALD, I. YAGAI, M.H. ZHANGE, 1990: Intercomparison and interpretation of climate feedback processes in 19 atmospheric general circulation models. - J. Geophys. Res. 95, 16601-16615.

Cook, J., E.J. Highwood, 2003: Climate response to tropospheric absorbing aerosols in an intermediate general circulation model. - Quart. J. Roy. Meteor. Soc. 130, 175-191.

DERWENT, R., R. FRIEDL, I.L. KAROL, V.W.J.H. KIRCHHOFF, T. OGAWA, M.J. Rossi, P. WENNBERG, 1999: Impacts of aircraft emissions on atmospheric ozone. - In J.E. Penner, D.H. Lister, D.J. Griggs, D.J. Dokken, M. MCFARLAND (Eds): Aviation and the Global Atmosphere. A Special Report of IPCC Working Groups I and III. Cambridge University Press, Cambridge, UK, 27-64.
Fahey, D.W., U. Schumann, S. Ackerman, P. Artaxo, O. Boucher, M.Y. Danilin, B. KÄrcher, P. Minnis, T. NAKAJIMA, O.B. ToOn, 1999: Aviationproduced aerosols and cloudiness. - In J.E. PENNER, D.H. Lister, D.J. GRigGS, D.J. DOKKEN, M. MCFARLAND (Eds): Aviation and the Global Atmosphere. A Special Report of IPCC Working Groups I and III. Cambridge University Press, Cambridge, UK, 65-120.

Fichter, C., S. Marquart, R. SAusen, D.S. Lee, 2005: The impact of cruise altitude on contrails and related radiative forcing. - Meteorol. Z. 14, 563-572.

FuglestVedT, J.S., T.K. BERNTSEN, O. GODAL, R. SAusen, K.P. Shine, T. Skodvin, 2003: Metrics of climate change: Assessing radiative forcing and emission indices. - Climatic Change 58, 267-331.

GAUSS, M., I.S.A. ISAKSEN, S. WONG, W.-C. WANG, 2003a: The impact of $\mathrm{H}_{2} \mathrm{O}$ emissions from kerosene aircraft and cryoplanes on the atmosphere. - J. Geophys. Res. 108, DOI:10.1029/2002JD002623.

Gauss, M., G. Myhre, G. Pitari, M.J. Prather, I.S.A. IsAKsen, T.K. BERntSEn, G.P. Brasseur, F.J. DENtener, R.G. Derwent, D.A. Hauglustaine, L.W. Horowitz, D.J. JACOB, M. JOHNSON, K.S. LAW, L.J. Mickley, J. F. Müller, P.-H. Plantevin, J.A. Pyle, H.L. Rogers, D.S. Stevenson, J.K. Sundet, M. VAN WeEle, O. WILD, 2003b: Radiative forcing in the 21 st century due to ozone changes in the troposphere and the lower stratosphere. - J. Geophys. Res. 108, 4292, DOI:10.1029/2002JD002624.

Grewe, V., M. DAmeris, C. Fichter, R. SAUSEN, 2002: Impact of aircraft NOx emissions. Part 1: Interactively coupled climate-chemistry simulations and sensitivities to climate-chemistry feedback, lightning and model resolution. - Meteorol. Z. 11, 177-186.

HARTMANN, D.L., M.E. OCKert-Bell, M.L. MiChELSEN, 1992: The effect of cloud type on earth's energy balance: Global analysis. - J. Climate 5, 1281-1304.

HAUGlustaine, D.A., F. Hourdin, S. Walters, L. Jourdain, M.-A. Filiberti, J.-F. Larmarque, E.A. HOLlAND, 2004: Interactive chemistry in the Laboratoire de Météorologie Dynamique general circulation model: Description and background tropospheric chemistry evaluation, - J. Geophys. Res. 109, DOI:10.1029/2003JD003957.

Hein, R., M. DAmeris, C. Schnadt, C. LAND, V. Grewe, I. Köhler, M. Ponater, R. Sausen,. B. STEIL, J. LANDGRAF, C. BRÜHL, 2001: Results of an interactively coupled atmospheric chemistry-general circulation model: Comparison with observations. - Ann. Geophys. 19, 435-457.

IPCC, 1999: see PENNER et al., 1999.

-, 2001: Climate Change 2001 - The Scientific Basis. Contributions of working group I to the Third Assessment Report of the Intergovernmental Panel on Climate Change. - Cambridge University Press, Cambridge, UK and New York, NY, USA, 881 pp.

ISAKSEN, I., C. JACKMAN, S. BAUghCUM, F. DENTENER, W. Grose, P. Kasibhatla, D. Kinnison, M.K.W. Ko, J.C. MCConnel, G. Pitari, D.J. Wuebbles, 1999: Modeling the chemical composition of the future atmosphere. - In J.E. PENNER, D.H. Lister, D.J. GRIGGS, D.J. 
DOKKEN, M. MCFARLAND (Eds): Aviation and the Global Atmosphere. A Special Report of IPCC Working Groups I and III. Cambridge University Press, Cambridge, UK, 121163.

Joshi, M., K. Shine, M. Ponater, N. Stuber, R. SAUSEN, L. LI, 2003: A comparison of climate response to different radiative forcings in three general circulation models: towards an improved metric of climate change. Climate Dyn. 20, 843-854.

KÄRCHER, B., U. LOHMANN, 2003: A parameterization of cirrus cloud formation: Heterogeneous freezing. - J. Geophys. Res. 108, 4402, DOI:10.1029/2002JD003220.

KÖHLER, M.O., 2003: Modelling the global impact of nitrogen oxides from subsonic aircraft emissions on ozone. - Ph.D. dissertation, Chemistry Department, University of Cambridge, Cambridge, UK, 259 pp.

Kraabøl A.G., F. Stordal, T. Berntsen, J. Sundet. 2002: Impacts of NOx emissions from subsonic aircraft in a global 3-D CTM including plume processes. - J. Geophys. Res. 10, 1029/2001JD001019.

Kristensson, A., J.-F. Gayet, J. Ström, F. Auriol, 2000: In situ observations of a reduction in effective crystal diameter in cirrus clouds near flight corridors. - Geophys. Res. Lett. 27, 681-684.

LAW, K.S., P.-H. Plantevin, V. Thouret, A. Marenco, W.A.H. Asman, M. LAWrence, P.J. Crutzen, J. F. Muller, D.A. Hauglustaine, M., KANAKIDOU, 2000: Comparison between global chemistry transport model results and Measurement of Ozone and Water Vapor by Airbus In-Service Aircraft (MOZAIC) data. - J. Geophys. Res. 105, DOI:10.1029/1999JD900474, 1503-1526.

LeE, D.S., R. SAusen, 2000: New Directions: Assessing the real impact of $\mathrm{CO}_{2}$ emissions trading by the aviation industry. - Atmos. Environ. 34, 5337-5338.

Mannstein, H., U. SCHUMANN, 2005: Aircraft induced contrail cirrus over Europe. - Meteorol. Z. 14, 549-554.

MARquART, S., B. MAYER, 2002: Towards a reliable GCM estimation of contrail radiative forcing. - Geophys. Res. Lett. 29, 1179, DOI: 10.1029/2001GL014075.

Marquart, S., M. Ponater, F. Mager, R. SAusen, 2003: Future development of contrail cover, optical depth and radiative forcing: Impacts of increasing air traffic and climate change. - J. Climate 16, 2890-2904.

MeERKötter, R., U. SCHUMANN, P. Minnis, D.R. DoElling, T. NAKAJIMA, Y. TSUShima, 1999: Radiative forcing by contrails. - Ann. Geophys. 17, 1080-1094.

Meyer, R., H. MAnnstein, R. MeERKÖtTER, U. SCHUMANN, P. WENDLING, 2002: Regional radiative forcing by line-shaped contrails derived from satellite data. - J. Geophys. Res. 107 (D10), 4104, DOI: 10.1029/2001JD000426.

Minnis, P., D. F. YOUnG, D. P. Garber, L. NGUYEN, W. L. SMith JR., R. PAlikONDA, 1998: Transformation of contrails into cirrus during SUCCESS. - Geophys. Res. Lett. 25, 1157-1160.

Minnis, P., U. SChumann, D.R. Doelling, K. GIERENS, D.W. FAHEY, 1999: Global distribution of contrail radiative forcing. - Geophys. Res. Lett. 26, 18531856.

Minnis, P., J.K. Ayers, R. Palikonda, D. Phan, 2004: Contrails, cirrus trends, and climate. - J. Climate 17, 16711685 .
Myhre, G., F. Stordal, 2001: On the tradeoff of the solar and thermal infrared radiative impact of contrails. - Geophys. Res. Lett. 28, 3119-3122.

PEnNer, J.E., D.H. Lister, D.J. Griggs, D.J. DokKen, M. MCFARLAND (Eds), 1999: Aviation and the global atmosphere. - A special report of IPCC working groups I and III. Intergovernmental Panel on Climate Change. - Cambridge University Press, Cambridge, UK and New York, NY, USA, 365 pp.

Pitari, G., E. MAncini, V. Rizi, D.T. Shindell, 2002: Impact of future climate and emission changes on stratospheric aerosols and ozone. - J. Atmos. Sci. 59, 414-440.

Ponater, M., S. Marquart, R. SAUSEN, 2002: Contrails in a comprehensive global climate model: Parameterisation and radiative forcing results. - J. Geophys. Res. 107, DOI:10.1029/2001JD000429.

Prather, M., R. Sausen, A.S. Grossman, J.M. HaYwood, D. Rind, B.H. SubBarayA, 1999: Potential climate change from aviation. - In J.E. PENNER, D.H. LISTER, D.J. GRIGGS, D.J. DOKKEN, M. MCFARLAND (Eds): Aviation and the Global Atmosphere. A Special Report of IPCC Working Groups I and III. Cambridge University Press, Cambridge, UK, 185-215.

Sausen, R., D. Nodorp, C. LAnd, F. DeidewiG, 1996: Ermittlung optimaler Flughöhen und Flugrouten unter dem Aspekt minimaler Klimawirksamkeit. DLRForschungsbericht 96-13, ISSN 0939-2963, 105 pp.

Sausen, R., C. Fichter, G. Amanatidis (Eds), 2004: European Conference on: Aviation, Atmosphere and Climate (AAC) - Proceedings of an International Conference. Air pollution research report 83, European Commission, 369 pp.

SCHUMANN, U., P. WENDLING, 1990: Determination of contrails from satellite data and observational results. - In SchumanN, U. (Ed.): Air Traffic and the Environment Background, Tendencies and Potential Global Atmsopheric Effects. - Lecture Notes in Engineering No. 60, SpringerVerlag, Berlin, Heidelberg, ISBN 3-540-53352-4, 138-153.

Shine, K.P., R.G. DerWEnt, D.J. WuebBles, J.-J. MorCRETTE, 1990: Radiative forcing of climate. - In Houghton, J.T., G.J. Jenkins, J.J. Ephraums (Eds): Climate Change: The IPCC Scientific Assessment. Cambridge University Press, Cambridge, United Kingdom and New York, NY, USA, 41-68.

Stordal, F., G. Myhre, D.W. Arlander, T. Svendby, E.J.G. STORDAL, W.B. Rossow, D.S. LEE, 2005: Is there a trend in cirrus cloud cover due to aircraft traffic? - Submitted to Atmos. Chem. Phys. See also Stordal et al., 2004, Atmos. Chem. Phys. Discuss. 4, 6473-6501.

STRÖM, J, S. OHLSSON, 1998: In situ measurements of enhanced crystal number density in cirrus clouds caused by aircraft exhaust. - J. Geophys. Res. 103, 11355-11361.

Stuber, N., R. SAUSEn, M. PonATER, 2001: Stratosphere adjusted radiative forcing calculations in a comprehensive climate model. - Theor. Appl. Climatol. 68, 125-135.

Zerefos, C.S., K. Eleftheratos, D.S. Balis, P. ZANis, G. Tselioudis, C. Meleti, 2003: Evidence of impact of aviation on cirrus cloud formation. - Atmos. Chem. Phys. 3, 1633-1644. 